\title{
Spathulenol as the most abundant component of essential oil of Moluccella aucheri (Boiss.) Scheen
}

\author{
Mina Doorandishan ${ }^{1,2}$, (D) Morteza Gholami ${ }^{1}$, (D) Pouneh Ebrahimi ${ }^{1}$ and (D) Amir Reza Jassbi ${ }^{2}$, \\ ${ }^{1}$ Department of Chemistry, Faculty of Sciences, Golestan University, Gorgan, IRAN \\ ${ }^{2}$ Medicinal and Natural Products Chemistry Research Center, Shiraz University of Medical Sciences, Shiraz, IRAN \\ *Corresponding author. Email: jassbiar@sums.ac.ir; arjassbi@hotmail.com
}

Submitted: 01.11.2020; Accepted: 17.03.2021

\begin{abstract}
The genus Moluccella (Lamiaceae) encompasses eight species among which Moluccella aucheri (Boiss.) Scheen and M. laevis L. are available in Iran. The aim of this study is characterizing the essential oil of dried aerial parts of $M$. aucheri collected from the South of Iran. The essential oil was hydrodistilled and then analysed by GC-MS. Twenty-one compounds were identified in the oil of $M$. aucheri. The most abundant components of the oil were an aromadendrane sesquiterpene; spathulenol (63.3\%) together with a diterpenoid; phytol (3.5\%) and a linear sesquiterpene, E-nerolidol (3.1\%).
\end{abstract}

Keywords: Essential oil, Moluccella aucheri, spathulenol, Lamiaceae

\section{Introduction}

Moluccella aucheri (Boiss.) Scheen (syn. Otostegia aucheri Boiss.) belongs to Moluccella genus and is native to Iran and Pakistan (Scheen \& Albert, 2007, 2009). This genus encompasses eight species which are widely distributed in South-Western Asia and the Mediterranean (http://wcsp.science.kew.org/). There are only two species of Moluccella genus reported from Iran; M. aucheri and M. laevis L. of which the earlier is growing wild in the South of the country (Mozaffarian, 2013).

M. aucheri is described previously as Otostegia aucheri Boiss. and is a shrub of perennial, growing 30 to 60 $\mathrm{cm}$ or rarely up to $80 \mathrm{~cm}$, with leaves of slightly fleshy, pale green, narrow, spinose-apiculate (pungent) flowering branches, multiple flower cycles, funnel-shaped calyx and white flowers (Jamzad, 2012). M. aucheri is used as a hair tonic and herbal medicine to prevent hair lost, also it is used for strengthening gums and dental cleanings in Iranian traditional medicine (Sadeghi et al., 2014).

Based on the molecular analysing investigations, $M$. aucheri is suggested as a sister of the two species $M$. laevis L. and M. spinosa L. (Scheen \& Albert, 2009). Recent GC-MS analysis of the essential oil (EO) of the flowers of $M$. laevis exhibited $\alpha$-pinene, chrysanthenyl acetate, and isobornyl acetate as the major constituents, while isobornyl acetate, 2-methyl-4-butanolide, 1-heptene oxide and methyl benzoate were detected in the oil of the plants' leaves (Hamed et al., 2020). In another attempt, the EOs' constituents of $M$. laevis were characterized by GC-MS as $\alpha$-pinene, pinocarvone, methyl chavicol and $\beta$-caryophyllene (Shehata, 2001). The EO of M. spinosa was analysed by GC-MS and $\alpha$-pinene, caryophyllene oxide, $\beta$ caryophyllene were reported as its major components (Casiglia et al., 2015).

To the best of our knowledge, this is the first phytochemical report on M. aucheri. 


\section{Materials and Methods}

\section{Plant material}

Moluccella aucheri (Boiss.) Sheen was collected during its flowering stage in May 2017, from Hormozgan

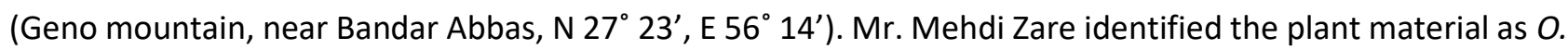
aucheri syn. M. aucheri and deposited voucher specimens (PC-96-3-23-3.1) in the Herbarium of Medicinal and Natural Products Chemistry Research Center, Shiraz University of Medical Sciences (MNCRC), Shiraz, Iran (Jamzad 2012).

\section{Extraction of the essential oil}

The aerial parts of $M$. aucheri was dried in the shade (100 g) and was subjected to hydrodistillation for extraction of the EO using a British Pharmacopoeia (BP) apparatus for $3 \mathrm{~h}$. A yellow EO (100 mg, $0.1 \% \mathrm{w} / \mathrm{w})$ was obtained and dried over anhydrous $\mathrm{Na}_{2} \mathrm{SO}_{4}$ and stored at $-20{ }^{\circ} \mathrm{C}$ until further GC-MS analyses (Jassbi et al., 2018).

\section{GC-MS analyses}

GC-MS analysis was carried out on an Agilent $7890 \mathrm{~N}$ chromatograph apparatus, equipped with HP-5 capillary column (30 $\mathrm{m} \times 0.25 \mathrm{~mm} \times 0.25 \mu \mathrm{m}$ film thickness). The GC was coupled to an Agilent 5975C mass spectrometer (Agilent Technologies, USA). The injection volume was $1 \mu \mathrm{L}$ and the flow rate of the carrier gas (helium) was $1 \mathrm{~mL} / \mathrm{min}$. The oven temperature increased from $60^{\circ} \mathrm{C}$ to $250{ }^{\circ} \mathrm{C}$ with the temperature rate of $5{ }^{\circ} \mathrm{C} / \mathrm{min}$ and $10 \mathrm{~min}$ remained at the final temperature. The ionization was taken in an $\mathrm{El}$ mode at $70 \mathrm{eV}$ followed by scanning the fragments ions in the octapole-quadropole analyser with $0.5 \mathrm{~s} / \mathrm{scan}$. The split ratio was 1: 10 (Asadollahi et al., 2019).

\section{Identification of the oil's compositions}

The relative retention index (RRI) was calculated for each of the GC-MS peaks in the chromatogram, relative to a series of $n$-alkane (C8-C20), with the Van den Dool formula (Van Den Dool \& Kratz, 1963). Identification of the compounds was performed with the comparison of their mass spectra and calculated RRI with those of authentic samples presented in the literature (Adams, 2007).

\section{Results and Discussion}

The aerial parts of $M$. aucheri were subjected to hydrodistillation extraction to afford a yellow oil with 0.1 w/w yield. The GC-MS analysis of the EO resulted in characterization of 21 compounds (Table 1). The major constituents of the oil were an aromadendrane sesquiterpene; spathulenol (63.3\%) together with bicyclogermacrene (3.7\%), two diterpenoids; phytol (3.5\%), sclareol (3.5\%) and a linear sesquiterpene; $E$ nerolidol (3.1\%). The monoterpenoids constituted only a small fraction of the oil $(3.3 \%)$, while the sesquiterpenoids (63.3\%) and diterpenoids (8.2\%) were the most abundant constituents of the oil, respectively (Table 1 )

Table 1: The GC-MS area\% of the essential oil of M. aucheri

\begin{tabular}{lllll}
\hline & Compounds & Area & RR $_{\text {exp }}$ & RR $_{\text {lit }}$ \\
\hline 1 & 1-octen-3-ol & $\mathrm{t}$ & 998 & 974 \\
2 & linalool & 0.9 & 1116 & 1095 \\
3 & bornyl acetate & 0.8 & 1289 & 1287 \\
4 & -elemene & $\mathrm{t}$ & 1333 & 1335 \\
\hline
\end{tabular}




\begin{tabular}{|c|c|c|c|c|}
\hline & Compounds & Area \% & RRI $\mathbf{l e x p}$ & $\mathbf{R R I}_{\text {lit }}$ \\
\hline 5 & $\alpha$-cubebene & $\operatorname{tr}$ & 1346 & 1345 \\
\hline 6 & $\alpha$-terpinol acetate & 1.6 & 1354 & 1346 \\
\hline 7 & dodecanal & 0.1 & 1418 & 1408 \\
\hline 8 & $\beta$-caryophyllene & 1.6 & 1422 & 1417 \\
\hline 9 & $\alpha$-humulene & 1.1 & 1458 & 1452 \\
\hline 10 & germacrene $D$ & 1.1 & 1484 & 1484 \\
\hline 11 & bicyclogermacrene & 3.7 & 1500 & 1500 \\
\hline 12 & E-nerolidol & 3.1 & 1582 & 1561 \\
\hline 13 & spathulenol & 63.3 & 1606 & 1577 \\
\hline 14 & humulene epoxide II & 2.1 & 1621 & 1608 \\
\hline 15 & 2-pentadecanone-6,10,14-trimethyl & 1.1 & 1849 & $1846^{*}$ \\
\hline 16 & farnesyl acetone $C$ & $\operatorname{tr}$ & 1919 & 1860 \\
\hline 17 & sclareol oxide & 0.4 & 1988 & $1906^{*}$ \\
\hline 18 & manool oxide & 0.2 & 2008 & 1987 \\
\hline 19 & $E, E$-geranyl linalool & 0.6 & 2037 & 2026 \\
\hline 20 & phytol & 3.5 & 2130 & $1942,2135^{*}$ \\
\hline \multirow[t]{6}{*}{21} & sclareol & 3.5 & 2253 & 2222 \\
\hline & monoterpenes & 3.3 & & \\
\hline & sesquiterpene & 76.0 & & \\
\hline & diterpenes & 8.2 & & \\
\hline & other compounds & 1.2 & & \\
\hline & Total & 88.7 & & \\
\hline
\end{tabular}

$\mathrm{RRI}_{\text {exp: }}$ Experimental Relative retention indices calculated using the retention times of a series of $\left(\mathrm{C}_{8^{-}} \mathrm{C}_{40}\right) n$-alkanes, RRI lit: RRI reported from a nonpolar GC column in the literature (Adams, 2007), or * National Institute of Standard and Technology, NIST Chemistry Web book (https://webbook.nist.gov/chemistry/name-ser/), $\operatorname{tr}=\operatorname{trace}(<0.05 \%)$.

In a recent study, caryophyllene oxide (20.7\%), spathulenol (14.9\%), (E)-nerolidol (8.0\%), and phytol (9.2\%) were reported as major compounds of essential oil from Stevia rebaudiana Bertoni leaf. These compounds showed insecticidal effects against aphids; Metopolophium dirhodum (Walker, 1849), one of the main pests of cereals. Finally, phytol, $(E)$-nerolidol and spathulenol were introduced as environmentally-friendly insecticides against aphids (Benelli et al., 2020). Given in our study, these three compounds represent $69.9 \%$ of total EOs of $M$. aucheri, so the oil is suggested for further investigation for the production of green insecticides against aphids.

Spathulenol is a tricyclic sesquiterpene with 5,10-cycloaromadendrane skeleton. A literature survey indicated that spathulenol has important bioactivity such as anticholinesterase (Karakaya et al., 2020), antinociceptive, anti-hyperalgesic (Dos Santos et al., 2020), anti-mycobacterial (de Jesús Dzul-Beh et al., 2019; do Nascimento et al., 2018), antioxidant, anti-proliferative, anti-oedematogenic (do Nascimento et al., 2018), cytotoxicity (Mirzaei et al., 2017) and as chemotherapy adjuvant of MDR cancer (Martins et al., 2010). Since the EO of $M$. aucheri contains high levels of spathulenol, therefore, the above mentioned biological activities are expected for the oil, yet needs to be confirmed in the future.

In a recent study (Rosselli et al., 2019), M. aucheri was mistakenly synonymized to Ballota aucheri Boiss., a different, but taxonomically related plant of the Lamiaceae family (Jamzad 2012). To examine their similarity, we compared the EO composition of both species. The major constituents of $B$. aucheri oil were $\alpha$-cadinol (21.0\%), dehydroaromadendrane (11.8\%), $\beta$-caryophyllene (8.1\%), spathulenol (6.0\%), carvone (6.4\%) and 
linalool (4.8\%) (Rustaiyan et al., 2006). Although, the two plants are rich in sesquiterpenoids, but some of their major constituents are different. The presence of cadinol, dehydroaromadendrane and carvone in $B$. aucheri and phytol and sclareol in M. aucheri can be distinctive.

\section{Conclusion}

This is the first phytochemical analytical report on the medicinal plant, $M$. aucheri from the Southern parts of Iran. The detected compounds, spathulenol, sclareol, phytol, and nerolidol are known as potent biological active agents which may confirm a part of medicinal properties of the plant. Therefore, due to the high levels noteworthy of spathulenol, it is suggested that the oil of $M$. aucheri could contribute to the production of environment-friendly insecticides against pests of cereals. Although, we found differences and similarities between $B$. aucheri and $M$. aucheri, still more chemical analyses are required to distinguish these species based on their phytochemicals.

\section{ACKNOWLEDGMENT}

We thank Mr. Rahman Asadpour for his efforts in collection and Mr. Mehdi Zare for the identification of the plant. This study was kindly supported by SUMS (Shiraz University of Medical Sciences, Shiraz, Iran) and Golestan University (Gorgan, Iran) and is a part of PhD dissertation of Mina Doorandishan for the fulfilment of her degree.

\section{CONFLICTS OF INTEREST}

The authors have no conflicts of interest to declare.

\section{REFERENCES}

Adams, R. P. (2007). Identification of essential oil components by gas chromatography/mass spectrometry (Vol. 456): Allured publishing corporation Carol Stream, IL.

Asadollahi, M., Firuzi, O., Heidary Jamebozorgi, F., Alizadeh, M., \& Jassbi, A. R. (2019). Ethnopharmacological studies, chemical composition, antibacterial and cytotoxic activities of essential oils of eleven Salvia in Iran. Journal of Herbal Medicine, 17, 100250.

Benelli, G., Pavela, R., Drenaggi, E., Desneux, N., \& Maggi, F. (2020). Phytol, (E)-nerolidol and spathulenol from Stevia rebaudiana leaf essential oil as effective and eco-friendly botanical insecticides against Metopolophium dirhodum. Industrial Crops and Products, 155, 112844.

Casiglia, S., Jemia, M. B., Riccobono, L., Bruno, M., Scandolera, E., \& Senatore, F. (2015). Chemical composition of the essential oil of Moluccella spinosa L. (Lamiaceae) collected wild in Sicily and its activity on microorganisms affecting historical textiles. Natural Product Research, 29(13), 1201-1206.

de Jesús Dzul-Beh, A., García-Sosa, K., Uc-Cachón, A. H., Bórquez, J., Loyola, L. A., Barrios-García, H. B., Peña-Rodríguez, L. M., \& Molina-Salinas, G. M. (2019). In vitro growth inhibition and bactericidal activity of spathulenol against drugresistant clinical isolates of Mycobacterium tuberculosis. Revista Brasileira de Farmacognosia, 29(6), 798-800.

do Nascimento, K. F., Moreira, F. M. F., Santos, J. A., Kassuya, C. A. L., Croda, J. H. R., Cardoso, C. A. L., do Carmo Vieira, M., Ruiz, A. L. T. G., Foglio, M. A., \& de Carvalho, J. E. (2018). Antioxidant, anti-inflammatory, antiproliferative and antimycobacterial activities of the essential oil of Psidium guineense Sw. and spathulenol. Journal of Ethnopharmacology, 210, 351-358.

Dos Santos, E., Radai, J. A. S., do Nascimento, K. F., Formagio, A. S. N., de Matos Balsalobre, N., Ziff, E. B., Castelon Konkiewitz, E., \& Kassuya, C. A. L. (2020). Contribution of spathulenol to the anti-nociceptive effects of Psidium guineense. Nutritional Neuroscience, 1-11. 
Hamed, A., Ahmed, N., Attia, E., \& Desoukey, S. (2020). Phytochemical investigation of saponifiable matter \& volatile oils and antibacterial activity of Moluccella laevis L., family Lamiaceae (Labiatae). Journal of advanced Biomedical and Pharmaceutical Sciences, 3(4), 213-220.

Jamzad, Z. (2012). Flora of Iran, no. 76, Lamiaceae: Ministry of Jihad-e-Agriculture, Research Institute of Forests \& Rangelands Press, Iran.

Jassbi, A. R., Mirzaie, Y., Firuzi, O., \& Asadollahi, M. (2018). Composition and cytotoxic activity of the essential oils of Mentha mozaffarianii Jamzad at different phenological stages. Current Bioactive Compounds, 14(2), $191-196$.

Karakaya, S., Yilmaz, S. V., Özdemir, Ö., Koca, M., Pınar, N. M., Demirci, B., Yıldırım, K., Sytar, O., Turkez, H., \& Baser, K. H. C. (2020). A caryophyllene oxide and other potential anticholinesterase and anticancer agent in Salvia verticillata subsp. amasiaca (Freyn \& Bornm.) Bornm. (Lamiaceae). Journal of Essential Oil Research, 32(6), 512-525.

Martins, A., Hajdú, Z., Vasas, A., Csupor-Löffler, B., Molnár, J., \& Hohmann, J. (2010). Spathulenol inhibit the human ABCB1 efflux pump. Planta Medica, 76(12), P608.

Mirzaei, H. H., Firuzi, O., Baldwin, I. T., \& Jassbi, A. R. (2017). Cytotoxic activities of different Iranian solanaceae and lamiaceae plants and bioassay-guided study of an active extract from Salvia lachnocalyx. Natural Product Communications, 12(10), 1563-1566.

Mozaffarian, V. (2013). Identification of Medicinal and Aromatic Plants of Iran. Tehran: Farhang Moaser Press.

Rosselli, S., Fontana, G., \& Bruno, M. (2019). A review of the phytochemistry, traditional uses, and biological activities of the Genus Ballota and Otostegia. Planta Medica, 85(11-12), 869-910.

Rustaiyan, A., Masoudi, S., Ameri, N., Samiee, K., \& Monfared, A. (2006). Volatile constituents of Ballota aucheri Boiss., Stachys benthamiana Boiss. and Perovskia abrotanoides Karel. growing wild in Iran. Journal of Essential Oil Research, $18(2), 218-221$.

Sadeghi, Z., Kuhestani, K., Abdollahi, V., \& Mahmood, A. (2014). Ethnopharmacological studies of indigenous medicinal plants of Saravan region, Baluchistan, Iran. Journal of Ethnopharmacology, 153(1), 111-118.

Scheen, A. C., \& Albert, V. A. (2007). Nomenclatural and taxonomic changes within the Leucas clade (Lamioideae; Lamiaceae). Systematics and Geography of Plants, 77, 229-238.

Scheen, A. C., \& Albert, V. A. (2009). Molecular phylogenetics of the Leucas group (Lamioideae; Lamiaceae). Systematic Botany, 34(1), 173-181.

Shehata, I. (2001). A pharmacognostical study of Moluccella laevis L. Bull Facult Pharm (Cairo University), 39, $239-251$.

Van Den Dool, H., \& Kratz, P. (1963). A generalization of the retention index system including linear temperature programmed gas-liquid partition chromatography. Journal of Chromatography, 11, 463-471. 